\title{
The role of Universities in the Continuous Professional Development of the Russian Engineering Workforce
}

Dr. Phillip Albert Sanger, Purdue University, West Lafayette Julia Ziyatdinova, Kazan National Research Technological University

Prof. Svetlana Vasilievna Barabanova, Kazan National Research Technological University

Born in U.S.S.R., Barabanova graduated from Kazan State University in 1983 as a doctor of law. In 1986, Barabanova began working at what is now known as Kazan National Research Technological University. Barabanova is a specialist in educational law, and a participant in government commissions for educational reform legislation.

Dr. Vasiliy G. Ivanov, Kazan National Research Technological University 


\title{
The Role of the Institute of Additional Professional Education in Continuous Professional Development of the Tartarstan Engineering Workforce
}

\begin{abstract}
Continuous improvement and professional development of engineers in Russia is required of all engineers. This requirement is analogous to the continuing education required of teachers and medical professionals in the U.S. To satisfy this need, a special coordinating organization was founded at the regional state level, Interdisciplinary Republican Center of Professional Retraining and Raising Qualification of Leaders and Specialists of Tatarstan. All universities in Tatarstan are members of this body which forms the heart of a close collaboration between educational establishments and industry to develop and provide courses and curricula. The Institute of Additional Professional Education at Kazan National Research Technological University (IDPO KNRTU) plays an important role in creating programs based on industry input.
\end{abstract}

Approximately 500 engineers and staff from industry raise their qualification at KNRTU following a broad set of course offerings 72-500 contact hours depending on the focus with costs ranging from $\$ 100-300$ per course. Typical programs cover industrial and ecological safety, hazardous waste management, energy efficiency in HVAC and power management, protection of intellectual property including state security clearance as well as commercial trade secrets, industry specific technical course for the oil and gas industry such as qualification of fuel filling stations staff, the proper maintenance and protection of pipelines and occupational and health safety issues and training for the industry.

The Russian government policy today aims at rigid requirements to the professional standards and qualifications of the workforce. They require continuous professional development of the workforce making owners of the enterprises include this in their budgets. By comparison with 1990, the situation has significantly improved today. In earlier times industry could decide themselves how to manage their budgets which caused overspendings on salaries for top management, underpayments for employees, deterioration of capital equipment, and illiteracy of the workforce concerning the modern trends in production and industrial safety. This situatio lead to a high incidence of preventable industrial accidents. Overall quality and industrial occupational safety is rising, and the government policy favors industrial safety rather than very high profits at any costs. The demand for the workforce in the market has shifted from the "buy and sell' business to qualified engineering professions. This improvement has been driven by government regulation requiring professional retraining of the workforce. Educational institutions who can provide this training have to compete in the market for the funding and for the industrial enterprises as their clients. This is a general trend across all of the Russian Federation. In order to survive in this competition, educational institutions must offer programs which are in demand, and institutional survival is proof of their effectiveness in responding to customer needs. In general, the market of educational services for industrial enterprises is developing and it is important to distinguish the main successful players in this market and study their experience in order to duplicate and multiply it. 
Kazan National Research Technological University (KNRTU) is one of 29 Russian Universities with the status of National Research University. Situated in the Republic of Tatarstan, one of the regions of Russia with advanced industrial development and innovations, KNRTU is the leading Russian university in chemical engineering. Its history dates back to 1890 when the Ministry of Public Education of the Russian Empire enacted the resolution to establish the Integrated Industrial and Technical College. Great attention is given by the University to continuing professional development. This focus resulted in the adoption in 2008 of the Program 2008-2012 of study. Professional developmentis a key element of innovation development of University and work is focusing on increasing the number of licensed professional development programs. The University implements continuous educational cycle of training, skills upgrading and retraining of managers and specialists of branches of economy, as well as high school teachers.

The Institute of Additional Professional Education (IDPO) is one of the structural subdivisions of KNRTU focus exclusively on continued professiona development of the workforce. Founded in 1998, it was organized for the specific purpose of advanced training of teachers and technical training for the Kazan chemical-technological Institute. An integrated approach has created a qualitatively new system of training and advanced training of teachers and professors of engineering universities as the basis of their professional development and improving the quality of graduates. High school became the base of Russian education in higher school teachers ' inservice training programs in priority areas. Programs are developed by the state accreditation of higher education and have the right to issue certificates of State standard requirements including the State educational standards of the Russian Federation. Training is provided by leading university experts, as well as the leading specialists of various industries industry. Degrees and evidence of completion include diplomas (volume programs not less than 500 hours), certificates (prolonged courses of over 100 hours) and certificate (of 72 courses up to 100 hours). Enrollment of students is made on the basis of contracts with individuals and/or legal entities.

IDPO runs over 50 programs of professional development. The dynamics of the last 3 years shows that around 1500 professionals and leaders from industrial enterprises raise their qualification every year at the Institute. The proof of the Institute efficiency is the self sufficiency of the Institute for 15 years without any state funding. In these 15 years the Institute has been aiming at changing the thinking of the leaders of industrial enterprises, who used to consider that there is no need for professional development of their workforce. They used to think that it is important to train only managers and administrators, while those who work in the production line can study in the workplace. Moreover, the general opinion is that the university is not the place where workforce can get professional development. Today, many of them are changing their opinions due to the policy of the IDPO and the Interbranch Regional Center, supported by the Tatarstan Republic Authorities. 
Tatarstan is one of the most economically advanced regions of the Russian Federation. Many joint international projects are implemented in the Republic and many new enterprises are constructed on the territory of the Republic including large petroleum refineries and petrochemical plants. The state requirements for ecological and industrial safety at the enterprises have significantly grown in the last decade. However, the university graduates, and even experienced workers are not familiar with the latest regulations. Therefore there arises a need for special professional development courses. Kazan National Research Technological University (KNRTU) has expertise in this field, and Institute of Additional Professional Education develops special programs in Ecological Safety.

The professional development program in Ecological Safety was developed in 2006 and deals with hazardous wastes treatment, ecological management, environmental protection, including water and air treatment, overview of state regulations concerning the subject. The demand for this program has been stably high (see Table 1). Thus, over half of those who attend professional development courses at the Institute, are those who take training in ecological safety.

Table 1. Number of Professionals Attending the "Ecological Safety" Courses

\begin{tabular}{|l|l|l|l|l|l|l|}
\hline & $\mathbf{2 0 0 6}$ & $\mathbf{2 0 0 7}$ & $\mathbf{2 0 0 8}$ & $\mathbf{2 0 0 9}$ & $\mathbf{2 0 1 0}$ & $\mathbf{2 0 1 1}$ \\
\hline $\begin{array}{l}\text { Number of courses } \\
\text { attendants }\end{array}$ & 558 & 568 & 1023 & 774 & 820 & 956 \\
\hline
\end{tabular}

Another program which has always been in demand is Industrial Safety. One of the enterprises in the Republic which always sends its workforce for these courses is OAO

Nizhnekamskneftekhim, a dynamically developing high-tech petrochemical company

[http://www.nknh.ru/about_company_en.asp]. Every year around 300 of their workforce take professional development courses at Institute of Additional Professional Education, and the majority are in industrial safety (see Table 2). The company has a special subdivision responsible for professional development of the workforce, and the Director of the Study Center Andrey Nikolaev claims that the courses taken by their workforce at Institute of Additional Professional Education of KNRTU contribute greatly to the growth and prosperity of the company. The flexible approach, where classes are given both at university and directly at the work place is of a great advantage. The experience of the last years shows that the number of industrial accidents at this enterprise has fallen proving the effectiveness of the new policy where both requirements and legal regulations are followed, novel equipment is used at the most hazardous blocks and the workforce regularly goes through training courses and learn the latest information about the industrial and ecological safety.

Table 2. Number of Workforce from 'Nizhnekamsneftekhim' Attending Courses

\begin{tabular}{|l|l|l|l|}
\hline & $\mathbf{2 0 0 9}$ & $\mathbf{2 0 1 0}$ & $\mathbf{2 0 1 1}$ \\
\hline Industrial Safety & 200 & 300 & 200 \\
\hline Ecological Safety & 35 & 36 & 45 \\
\hline Other Programs & 60 & - & 56 \\
\hline
\end{tabular}

Another good example of cooperation between the IDPO and industry is the relationship with 
Gazprom, a huge Russian global energy company. Since 2005, more than 30 employees annually take 72 hour professional development courses in Vacuum and Compressor Engineering. The importance of this cooperation is proven by the fact that a representative of the company leadership always attends the start and the final of the program.

A new trend today is not only ecological and industrial safety but also Lean Production which comprises highly efficient manufacturing and management techniques. Teaching and learning materials have been developed in Lean Production for chemical and petrochemical enterprises. In 2011, 175 people from 5 different enterprises attended these courses.

Thus, the programs developed and implemented by IDPO at industrial enterprises of both the Tatarstan Republic and the Russian Federation scale have secured a solid and loyal customer base of companies proving the sustainability of the professional developments programs and the need for an institution of this type in Tatarstan.

\section{Summary}

The Institute of Additional Professional Education was created to meet the needs of industry and the Tartarstan region. Those needs have grown and become extremely diverse. The IDPO is filling a critical need in the industrial ecosystem of Tartarstan. 